\title{
Uranyl Nitrate Induced Histological Changes in Lung Tissue
}

\author{
Dr.Widad Jumaa Hamid \\ Assist Prof., College of Pharmacy, AL-Mustansriya University \\ Baghdad I Iraq
}

\begin{abstract}
Uranium is a naturally occurring radioactive material present everywhere in the environment. It is toxic because of its chemical or radioactive properties. Uranium enters environment mainly from mines and industry and cause threat to human health by accumulating in lungs as a result of inhalation. In our previous study, we have shown the effectiveness of antioxidant system response to the oxidative stress induced by Uranyl Nitrate (UN) in rat lung tissue. In the current study, uranium toxicity was evaluated in rat lung epithelial cells. The study shows uranium nitrate induces significant oxidative stress in rat lung epithelial cells followed by decrease in the antioxidant potential of the cells. Treatment with Uranyl Nitrate to rat lung epithelial cells was attributed to loss of total glutathione, thus the results indicate the ineffectiveness of antioxidant system's response to the oxidative stress induced by uranium in the cells. Histological study show slight degenerative changes in lung, pulmonary edema; hemorrhage; emphysema; inflammation of the bronchi; alveoli and alveolar interstices; edematous alveoli; lung lesions; minimal pulmonary hyaline fibrosis and pulmonary fibrosis.
\end{abstract}

Keywords-component; Uranium, Glutathione, Reactive oxygen species, Lipid peroxidation,Uranyl Nitrate

\section{INTRODUCTION}

Uranium, a heavy metal, is found widespread in nature, always in combination with other elements. Uranium has sixteen radioactive isotopes. Uranium isotopes, like other radioactive materials, emit ionizing radiation that is strong enough to damage or destroy living cells. Natural uranium emits gamma radiation and alpha particles. However, alpha radiation rarely appears without being accompanied by other emitters and because they penetrate a very short distance, these particles concentrate on a few micrometers of tissue and are therefore very harmful(1).

The more soluble compounds of uranium, namely, uranium hexafluoride, uranyl fluoride, uranium tetrachloride, uranyl nitrate hexahydrate, are likely to be absorbed into the blood from the alveolar pockets in the lungs within days of exposure(2). Although inhalation products also are transported through coughing and mucocilliary action to the gastro-intestinal tract only about 2 percent of this fraction is actually absorbed into the body fluids through the intestinal wall. Therefore all of the research papers on acute effects of uranium refer to these soluble uranium compounds via inhalation(3). The main acute effect of inhalation of soluble uranium compounds is damage to the renal system, and the main long term storage place of these compounds in the body is bone(4).

The increase in ROS was significant. DU by inhalation resulted in increase of inflammatory cytokine expression and production of hydro peroxides in lung tissue as a consequence of the inflammatory processes and oxidative stress (5 ) therefore, uranium is known to induce oxidative stress with the earlier findings.

Increase in oxidative stress could result from failure of the antioxidant system that constantly counteracts the formation of oxidative species in the cells. Heavy metals like $\mathrm{Pb}, \mathrm{Cd}, \mathrm{Hg}$ and $\mathrm{Cr}$ are capable of inducing oxidative stress both in vivo and in vitro (6). The cause of the oxidative stress due to these metals pertains to failure in antioxidant status in the system. Therefore, to look for a similar cause with uranium we estimated the levels of glutathione (GSH) in uranium treated animals with UN and compared to control(6)..

In addition to GSH, the antioxidant enzymes effective in scavenging free radicals (7). The above results suggest that the increase in ROS by UN in treated animals with UN were possibly due to the failure of the antioxidant mechanisms to counteract the rising oxidative species in lung. Therefore, supplementation of antioxidants could preferably counteract the oxidative stress induced by UN. As mentioned earlier, the route of exposure to uranium is largely through inhalation and therefore it makes the lung tissue as one of its target organs. DU of size $<5 \mu \mathrm{m}$ can lodge deep into the lung alveoli, thus producing toxicological impact at the site of contact Uranium toxic studies in lung reported the toxic response to the metal(8). 


\section{METHODS}

Twenty male rats (Rattus norvegicus) are used in this study, weighing (200- 210) g (six weeks age) housed in the animal house of the collage of science, university of Baghdad.

These animals were maintained of controlled temperature ( $25 \pm 2.2$ Cं) November 2013 to April 2014, allowed for accesses to water, and fed slandered rat chew added powder milk.20 male rats divided into two groups as follow.

Group I: Includes 10 animals used as control.

Group II: Included 10 animals treated with $75 \mathrm{mg} / \mathrm{kg}$ body weight UN for one month (administration and inhalation) .

Blood samples were obtained by heart puncture and immediately placed into the tubes then allowed to clot, serum was separated after centrifugation for 15 minutes at $2000 \mathrm{rpm}$ and the resulted serum were preserved frozen at (18Co ) unless immediate analysis was indicated.

Serum glutathione is determined by a modified procedure utilizing Ellman,s reagent (9)

\section{TISSUE PREPARATION}

Samples (Lung tissue) were fixed in 10\% neutral buffer formalin for $24-72$ hours and processed in routine manner to provide paraffin blocks. From each formalin fixed paraffin embedded specimen the 5 Micron section were cuts and mounted on clean slides. The $5 \mu \mathrm{m}$ paraffin sections were stained with Harris hematoxylin and eosin .

Table 1: Parameters of oxidative stress in Serum

\begin{tabular}{|l|l|l|}
\hline $\begin{array}{l}\text { Paramet } \\
\text { ers }\end{array}$ & $\begin{array}{l}\text { Group } \\
\text { treated with } \\
\text { UN GII } \\
\text { (mean } \pm \text { SD) }\end{array}$ & $\begin{array}{l}\text { Normal group GI } \\
\text { Control } \\
\text { (mean } \pm \text { SD) }\end{array}$ \\
\hline Number & 10 & 10 \\
\hline $\begin{array}{l}\mathrm{MDA} \\
\boldsymbol{\mu m o l} / \mathbf{g}\end{array}$ & $3.06 \pm 0.109$ & $1.29 \pm 0.198$ \\
\hline $\begin{array}{l}\text { GSH } \\
\boldsymbol{\mu m o l} / \mathbf{g}\end{array}$ & $1.88 \pm 0.212$ & $5 . .11 \pm 0.179$ \\
\hline
\end{tabular}

IV. STATISTICAL ANALYSIS:

The data of this study were complied into the computerized data file and the frequency, distribution and statistical description (mean, rang, and SD) were derived using SPSS statically software.

We used statistical analysis of variance (ANOVA) test and least significantly difference (LSD) test by probability of less than $0.05(\mathrm{P}<0.05)$ according to $(10)$.

With acute duration exposure this can lead to emphysema or pulmonary fibrosis .Animal studies demonstrate uranium compounds can cause adverse hematological disturbances (12).

\section{RESULTS}

The data in table((1),showed significant increment $(\mathrm{P}<(0.05)$ in animals group G II (75mg /Kg UN) in MDA levels after one month of treatment compare with control.

The data in table (2 ) show significant reduction $(\mathrm{P}<0.05)$ in animals group G II $(75 \mathrm{mg} / \mathrm{kg}$ UN)in GSH levels after one month of treatment compare with control .

Histological study showed slight degenerative changes in lung ,pulmonary edema; hemorrhage, emphysema ,inflammation of the bronchi, bronchial pneumonia, alveoli and alveolar interstices, edematous alveoli,, lung lesions, minimal pulmonary hyaline fibrosis and pulmonary fibrosis, in the lung tissue treated with $75 \mathrm{mg} / \mathrm{kg}$ body weight UN for one month(Fig.2,3,4,5,6) compare with control(Fig1). 

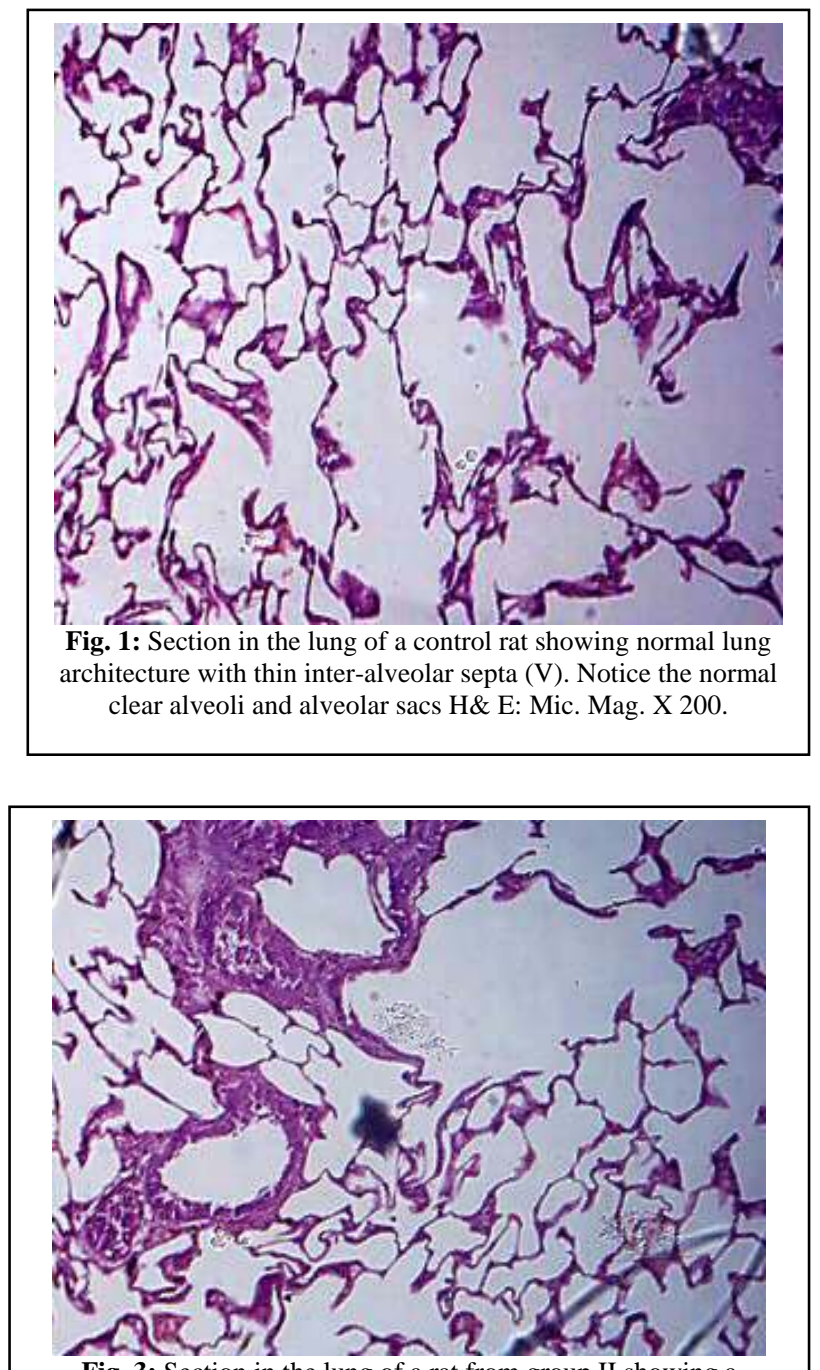

Fig. 3: Section in the lung of a rat from group II showing a congested blood vessel $(\mathrm{H})$ with interstitial cellular infiltration $(\mathrm{N})$

and presence of eosinophillic material in thickened inter-alveolar septa accompanied by narrowing of some alveolar air spaces (V) and widening ( W ) of other spaces. H\& E: Mic. Mag. X 200 


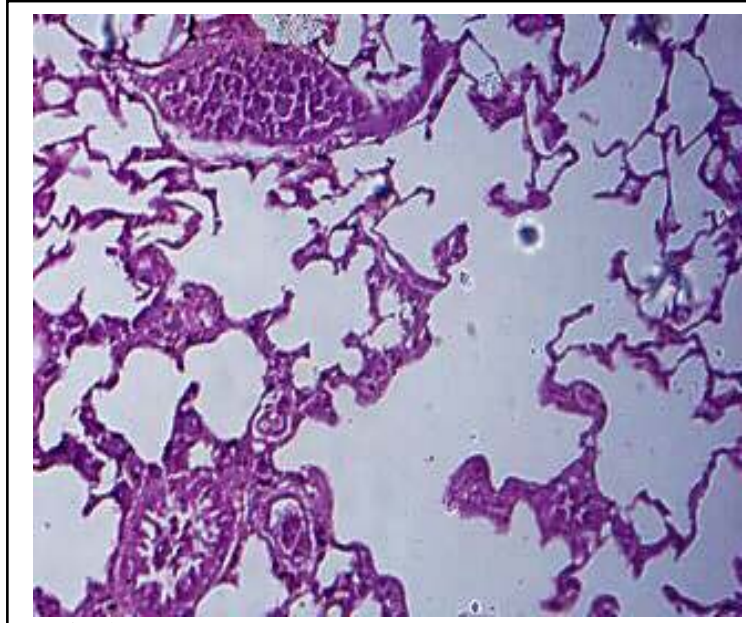

Fig. 2: Section in the lung of a rat from group II s howing a congested blood vessel ( $\mathrm{H}$ ) with interstitial cellular infiltration $(\mathrm{N})$ and presence of widening $(\mathrm{W})$ of other spaces. H\& E: Mic. Mag. X 200.

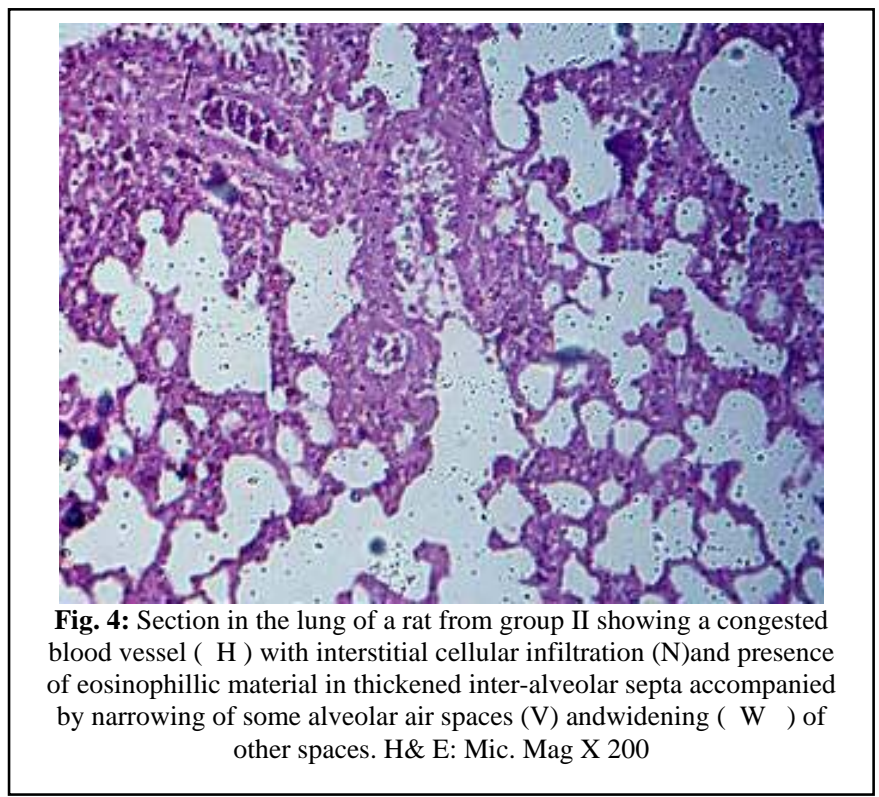



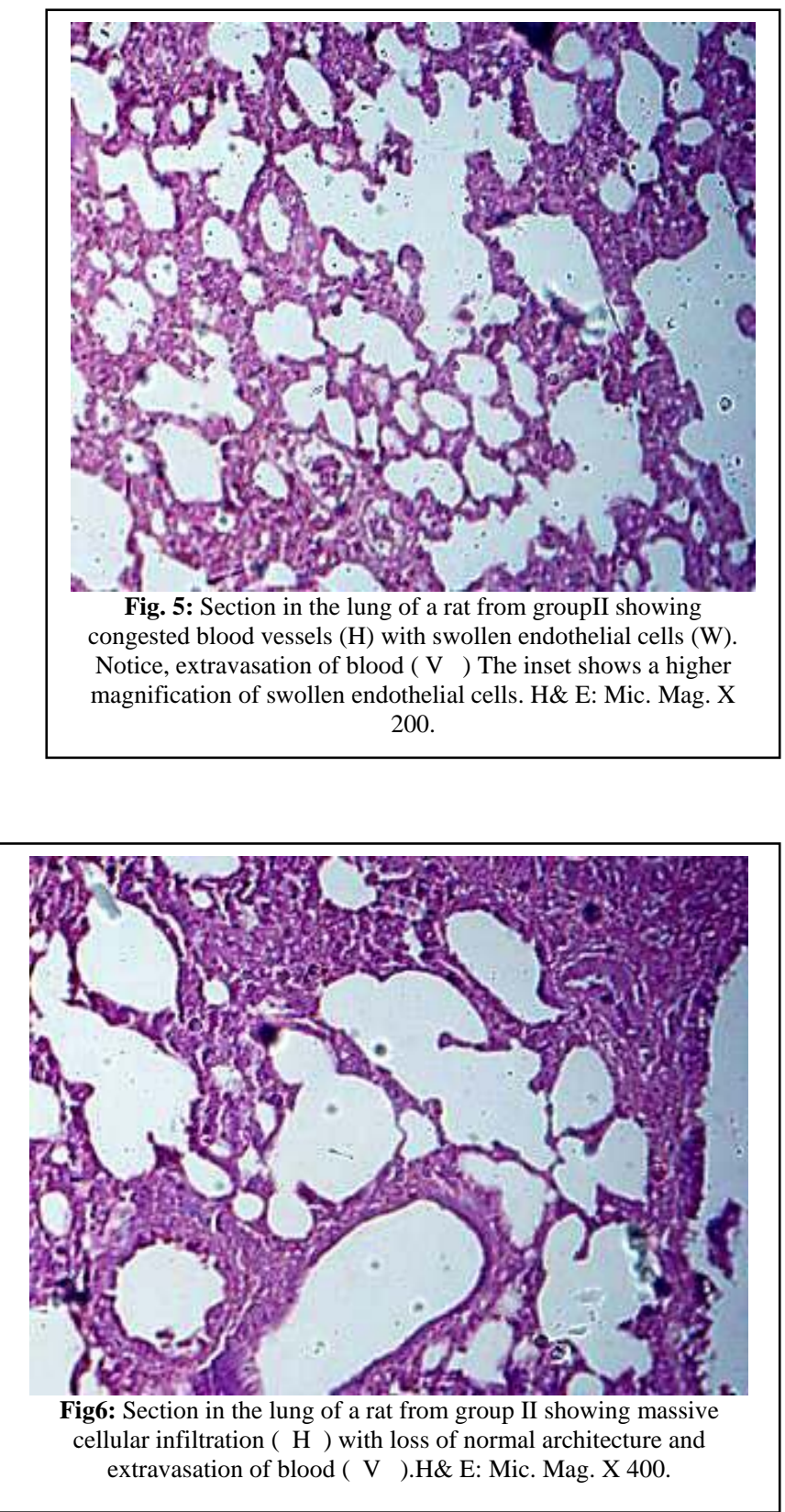

\section{DISCUSSION}

Metals can cause oxidative damage by free radical mechanism (Fenton type chemistry) or through direct interactions. Uranium has been earlier shown to produce DNA damaging hydroxyl radical in presence of ascorbate (11). There is also growing number of reports documenting the possibility of geno-toxicity by uranium possibly through a free radical mechanism. The vulnerability of the lung to uranium rises from the inhalation exposure route often encountered during occupational exposure and very few studies have reported on the toxic mechanism of uranium in lung. Our results have shown induction of oxidative stress by UN The induction of oxidative stress by heavy metals are known and in addition uranium is also a radioisotope. The increased ROS induce LPO and that may lead to cell membrane damage and subsequent cell death. Further, the toxic cell death by uranium might also be 
associated with the activation of apoptotic pathways induced by oxidative stress. Oxidative stress generated in cells is known to activate apoptotic pathways leading to cell death (12). The increase in ROS due to over production of oxidative radicals generated the oxidative stress by uranium. In addition to loss of GSH, decrease in the expression of SOD-2 by uranium also may be a reason for increase in ROS. SOD-2 is localized in the mitochondria and is involved in the production of oxygen free radicals in the mitochondria. However, the influence of ROS generated in the cytosol could be sufficient enough to affect the mitochondria. The oxidative stress generated due to loss of antioxidants can be restored by supplementation of antioxidants $(13,14)$. In the present study, we supplemented antioxidants and shown the protection against oxidative stress generated by Uranium. The effect of antioxidants suggest the generation of oxidative stress by uranium and the protection reveals the excessive generation of oxidative species leading to loss of antioxidant response and cell death.

Because of coughing and other involuntary mechanisms by which the body keeps large particles out of the lungs, the larger particles are excreted through the gastro-intestinal tract in feces. The uranium compounds which enter the body either through the wall of the gastro-intestinal tract or the lungs, can be broken down in the body fluids, and tetravalent uranium is likely to oxidize to the hexavalent form, followed by the formation of uranyl ions. Uranium generally forms complexes with citrate, bicarbonates or protein in plasma, and it can be stored in bone, lymph, liver, kidney or other tissues. Eventually this uranium which is taken internally is excreted through urine. Presence of depleted uranium in urine seven or eight years after exposure is sufficient evidence to substantiate long term internal contamination and tissue storage of this radioactive substance(15).

As mentioned earlier, the route of exposure to uranium is largely through inhalation and therefore it makes the lung tissue as one of its target organs. DU of size $<5 \mu \mathrm{m}$ can lodge deep into the lung alveoli, thus producing toxicological impact at the site of contact (Monleau et al. 2006). Uranium toxic studies in lung reported the toxic response to the metal (16). The impact of cancer risk upon uranium exposure is worked out in epidemiological studies. These studies have shown the risk of lung cancer in miners formerly exposed to uranium during mining (17). The occurrence of a genomic instability in lymphocytes of uranium miners, especially those who developed cancer was observed by studying the cytogenetic endpoint: marker micronuclei (Mn) (18). Further in vitro analysis with uranium acetate have shown significant increase in DNA single strand breaks in presence of ascorbic acid (12) However, there is little data in the literature and definitive statements are not possible. For these reasons dust inhalation is considered the most important route of exposure.

The differences in toxicity based on the solubility of the uranium compound (regardless of which uranium isotope is incorporated in the compound) are more striking: water soluble salts are primarily renal and systemic chemical toxicants; insoluble chemical compounds are primarily lung chemical toxicants and systemic radiological hazards. Once uranium dioxide enters the blood, hexavalent uranium is formed, which is also a systemic chemical toxicant.

The direct damage to lungs and kidneys by uranium compounds is thought to be the result of the combined radiation and chemical properties, and it is difficult to attribute

There is general agreement that inhalation of dust is probably the most significant route of exposure (19). Natural and depleted uranium shows little mobility in the soil but the particles can be re-suspended in the air and inhaled. However, there is little data in the literature and definitive statements are not possible. For these reasons dust inhalation is considered the most important route of exposure.

It may also be due to an inflammatory response of the lung tissue that begins to retard absorption after a few days( 20). Whatever the mechanism, inhaled DU appears to have a pulmonary half-life of about 4 years (21).

There is human research indicating that inhalation of insoluble uranium dioxide is associated with general damage to pulmonary structure, usually non-cancerous damage to alveolar epithelium. With acute duration exposure this can lead to emphysema or pulmonary fibrosis .Animal studies demonstrate uranium compounds can cause adverse hematological disturbances (12).

\section{REFERENCES}

[1] ATSDR 1998: "Toxicological Profile for Uranium" Draft for Public Comment, US Department of Health and Human Services, Public Health Service, Agency for Toxic Substances and Disease Ragistry, September 1997.

[2] Dick CAJ, Brown DM, Donaldson K, Stone V. The role of free radicals in the toxic and inflammatory affects of four different ultrafine particle types. Inhal Toxicol. 2003;1:39-52.

[3] Domej W, Foldes-Papp Z, Flogel E, Haditsch B. Chronic obstructive pulmonary disease and oxidative stress. Curr Pharm Biotechnol. 2006; 7:117-1123.

[4] Gazin V, Kerdine S, Grillon G, Pallardy M, Raoul H. Uranium induces TNF- $\alpha$ secretion and MAPK activation in a rat alveolar macrophage cell line. Toxicol Appl Pharmacol. 2004;1:49-59.

[5] Hussain S, Rodgers DA, Duhart HM, Ali SF. Mercuric chloride-induced reactive oxygen species and its effect on antioxidant enzymes in different regions of rat brain. J Environ Sci Health. 1977;32:395-409. 
[6] Kalinich JF, Ramakrishnan N, Villa V, McClain DE. Depleted uranium-uranyl chloride induces apoptosis in mouse J774 macrophages. Toxicology. 2002;179:105-114.

[7] Malard V, Prat O, Darrouzet E, Berenguer F, Sage N, Quemeneur E. Proteomic analysis of the response of human lung cells to uranium. Proteomics. 2005;5:4568-4580.

[8] Meister A. Glutathione, ascorbate, and cellular protection. Cancer Res. 1994;54:1969-1975.

[9] Sedlak J. and Lindsay R. H. Analytical Biochemistry , 1968 . Vol 314 : Pp 1311 -1317.

[10] Duncan , R. C, Knapp , R. G. and Miller M. C. Introductory Biostatistics of Health Sciences. A Wileg Medical Publication , John Wiley and Sons , London 1983. Pp: 161 -179 .

[11] Yazzie M, Gamble SL, Civitello ER, Stearns DM. Uranyl acetate causes DNA single strand breaks in vitro in the presence of ascorbate (vitamin C) Chem Res Toxicol. 2003;16:524-530.

[12] Cooper JR, Stradling GN, Smith H, et al 1982. "The behaviour of uranium 233 oxide and uranyl 233 nitrate in rats. International Journal of Radiation Biology and Related Studies in Physics, Chemistry and Medicine. Vol 41(4): 421-433.

[13] Cross FT, Palmer RF, Busch RH et al, 1981. "Development of lesions in Syrian golden hamsters following exposure to radon daughters and uranium dust". Health Physics Vol 41:1135-153.

[14] Dungworth DL. 1989 "Non-carcinogenic responses of the respiratory tract to inhaled toxicants." In: Concepts in Inhalation Toxicology. Editors: McClellan RO, and Henderson RF. Hemisphere Publ. Corp. New York NY.

[15] Saccamanno G, Thun MJ, Baker DB, et al 1982. "The contribution of uranium miners to lung cancer histogenesis renal toxicity in uranium mill workers". Cancer Research Vol. 82 43-52.

[16] Stokinger HE, Baxter RC, Dygent HP, et al 1953. In: Toxicity Following Inhalation for 1 and 2 Years. Editors: Voegtlin C and Hodge HC.

[17] Stradling GN, Stather JW, Gray SA, et al. "The metabolism of Ceramic Uranium and Non-ceramic Uranium Dioxide after Deposition in the Rat Lung." Human Toxicology 1988 Mar 7; Vol 7 (2): 133-139.

[18] Dygert HP 1949. Pharmacology and Toxicology of Uranium Compounds. Pages: 647-652, 666-672, and 673-675. McGraw Hill Books Inc.

[19] Stokinger HE, Baxter RC, Dygent HP, et al 1953. In: Toxicity Following Inhalation for 1 and 2Years. Editors: Voegtlin C and Hodge HC.

[20] Dublineau I, Grandcolas L, Grison S, Baudelin C, Paquet F, Voisin P, Aigueperse J, Gourmelon P. Modifications of inflammatory pathways in rat intestine following chronic ingestion of depleted uranium. Toxicol. Sci. 2007;98:458-468.

[21] Ghosh S, Kumar A, Pandey BN, Mishra KP. Acute exposure of uranyl nitrate causes lipid peroxidation and histopathological damage in brain and bone of Wistar rat. J. Environ. Pathol. Toxicol. Oncol. 2007;26:255-261. 